\title{
SECTOR SPIGOT COMPRESSIVE LOAD TEST \\ (EML-58)
}

\author{
Westinghouse Electric Corporation \\ Astronuclear Laboratory \\ P. O. Box 10864 \\ Pittsburgh, Pennsylvania 15236
}

PREPARED BY:

d. 9 . Rallin

NOTICE

This report was prepared as an account of work sponsored by the United States Government. Neither the United States nor the States Government. Neil her Commiss States nor the United States Atomic Energy Commission, nor any of their employees, nor any of their contractors, subcontractors, or their employees, makes any warranty, express or implied, or assumes any legal liability or responsibility for the accuracy, completeness or usefulness of any information, apparatus, product or process disciosed, or represents that its use would not infringe privately owned rights.

I. N. Kallin

Support Structure \& Cryogenic Experiments

\section{APPROVED BY:}

N.2. Bufano

N.J. Bifarlo, Supervisor

Support Structure \& Cryogenic Experiments

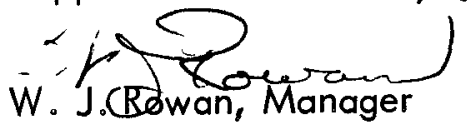

Engineering Mechanics

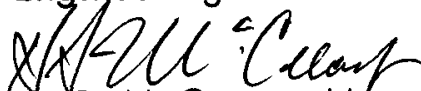

H. S. McCreary, Manager

Experimental Engifeering

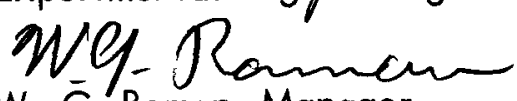

W. G. Roman, Manager

Reactor Engineering, NERVA Project
INFORMATION CATEGORY

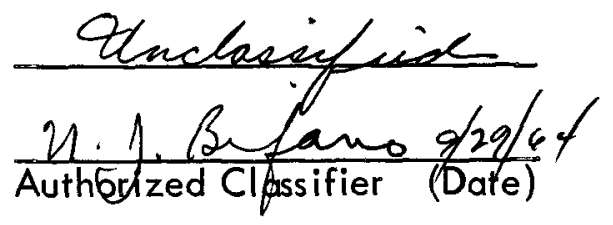

/fep 


\section{DISCLAIMER}

This report was prepared as an account of work sponsored by an agency of the United States Government. Neither the United States Government nor any agency Thereof, nor any of their employees, makes any warranty, express or implied, or assumes any legal liability or responsibility for the accuracy, completeness, or usefulness of any information, apparatus, product, or process disclosed, or represents that its use would not infringe privately owned rights. Reference herein to any specific commercial product, process, or service by trade name, trademark, manufacturer, or otherwise does not necessarily constitute or imply its endorsement, recommendation, or favoring by the United States Government or any agency thereof. The views and opinions of authors expressed herein do not necessarily state or reflect those of the United States Government or any agency thereof. 


\section{DISCLAIMER}

Portions of this document may be illegible in electronic image products. Images are produced from the best available original document. 


\section{TABLE OF CONTENTS}

\section{Page}

List of Figures

ii

Background

1

Test Procedure

1

Results

1

Conclusions

2

Figures

3

$-i-$ 


\section{LIST OF FIGURES}

Number

1

2

3

4

5
Title

Test Setup Showing End Plate, Sector and Tie Bolts

Simulated Reflector Nozzle End Support Ring Strain Gage Locations

End View of Sector Showing Diameters at Which Spigot Was Measured

Measured Plate Stresses, Gages 1, 2, 3, 7, 8

Measured Plate Stresses, Gages 4, 5, 6, 7, 8 $\underline{\text { Page }}$

3

4

5

6

7 


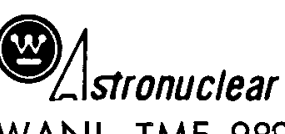

WANL-TME-989

\section{BACKGROUND}

Hoop-type compression loading in the reflector nozzle end support ring is believed to have occurred in the NRX-Al reactor tests due to transient differential thermal contractions between the support ring and pressure vessel. The objective of this test was to determine whether a $1000 \mathrm{lb}$ load of this type could cause sector spigot fracture when applied at room temperature. This load was estimated to be about twice as large as the load required to cause fracture of the spigot at reactor temperature conditions.

\section{TEST PROCEDURE}

An end plate, simulating a portion of the reflector nozzle end support ring, was assembled to a sector with tie bolts. The tie bolt nuts were torqued finger tight. The diametral clearance between the outside diameter of the sector spigot and the inside diameter of the simulated support ring spigot bore was $0.0002 \mathrm{in.}$ in the direction of loading.

The end plate was loaded in compression in a tensile testing machine (see Figure 1) and the plate strains, measured with the strain gages shown in Figure 2, were recorded at $50 \mathrm{lb}$ load increments from 0 to $1000 \mathrm{lb}$.

\section{RESULTS}

No fracture of the spigot or yielding of the simulated support ring was observed. However, post-test inspection of the sector spigot revealed that the spigot diameters at $\theta=0^{\circ}, 45^{\circ}, 90^{\circ}$, and $135^{\circ}$ (see Figure 3) had been reduced by 0 in., 0.0004 in., $0.0007 \mathrm{in}$. and 0.0003 in., respectively. This means that some plastic flow took place without fracture. The stresses measured by the strain gages on the simulated support ring are shown in Figures 4 and 5 . 


\section{CONCLUSIONS}

Since the sector spigot was not cracked at room temperature by a compressive load which was about twice as large as the load estimated to be capable of producing spigot failure at reactor temperature conditions, it is felt that the ductility change which the sector material (beryllium) undergoes when it is cooled from ambient to reactor operating temperature conditions has a very important effect on the load required to crack the spigot. Another test similar to the one described in this report will be performed at $140^{\circ} \mathrm{R}$ to determine the reflector nozzle end ring compressive load and resulting deflection required to crack the sector spigot under reactor temperature conditions. 


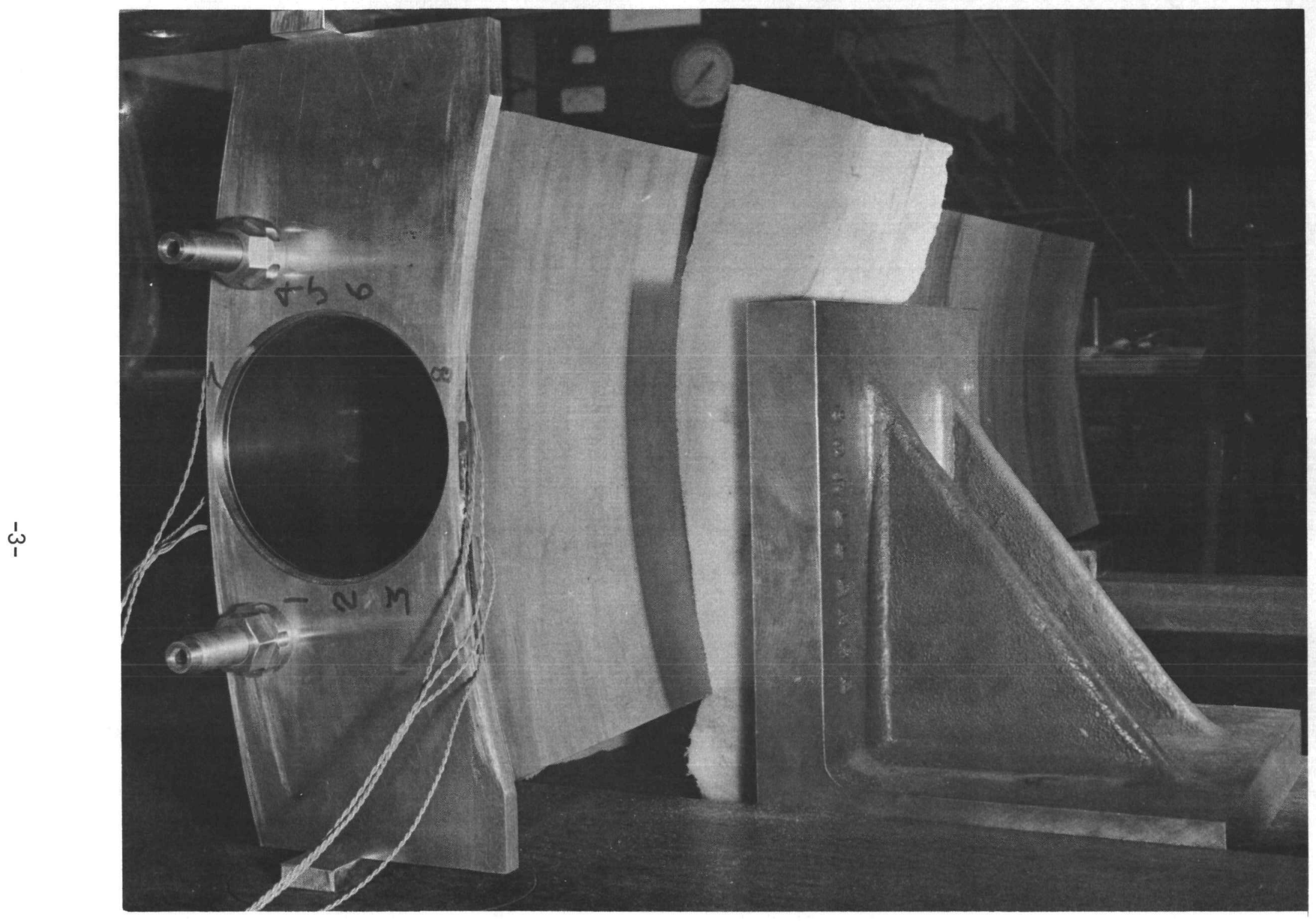

FIGURE 1

TEST SETUP SHOWING

END PLATE, SECTOR AND TIE BOLTS

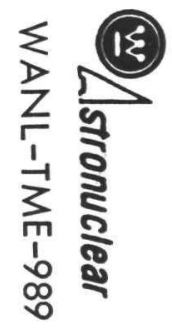




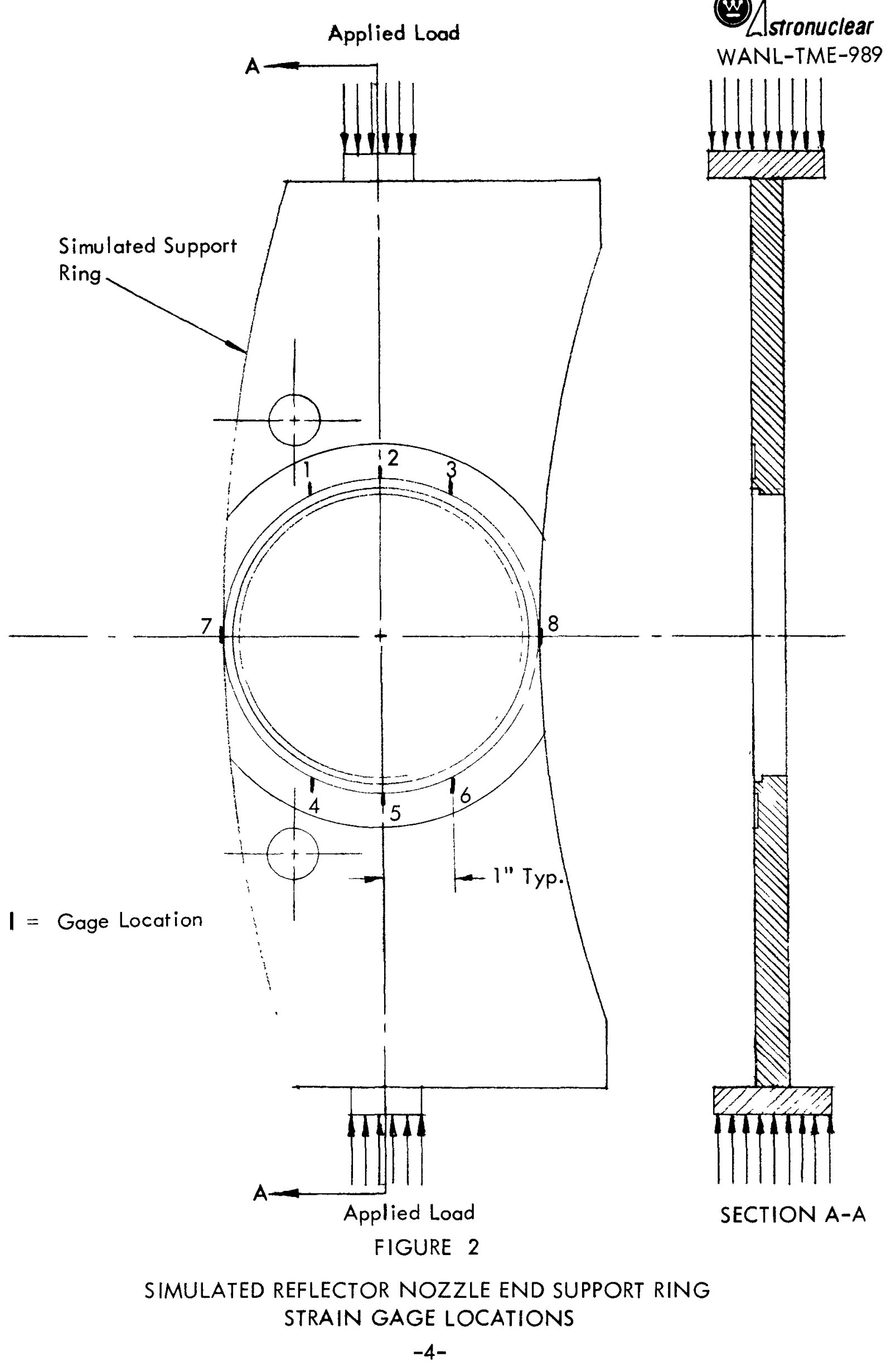




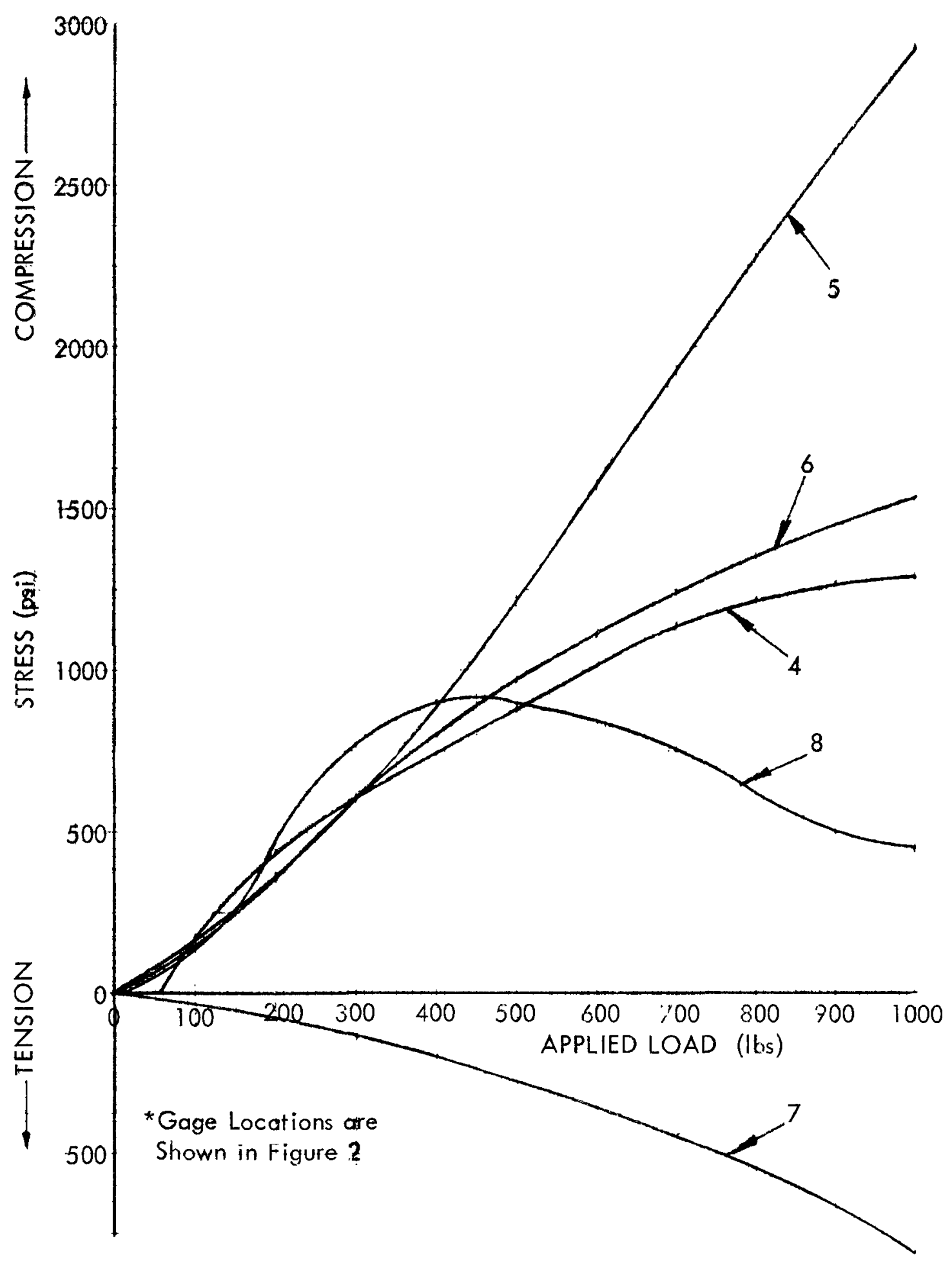

FIGURE 5

MEASURED PLATE STRESSES, GAGES $4,5,6,7,8^{*}$ 